\title{
BEÁGYAZOTT RENDSZER FEJLESZTÉSE TÖMEGSPEKTROMETRIÁS MÉRÉSEK ETHERNET ALAPÚ HÁLÓZATON VALÓ TOVÁBBÍTÁSÁRA
}

\section{DEVELOPMENT OF AN EMBEDDED SYSTEM FOR ACCESSING MASS SPECTROMETRY MEASUREMENTS THROUGH ETHERNET NETWORK}

\author{
Fekete Albert-Zsombor ${ }^{1}$, Jakab-Farkas László ${ }^{2}$ \\ Sapientia - Erdélyi Magyar Tudományegyetem, Marosvásárhelyi Kar, 540485, \\ Románia, Marosvásárhely, Segesvári út 1C; \\ Izsombor.fekete@tetronic.ro, ${ }^{2}$ jflaci@ms.sapientia.ro
}

\begin{abstract}
Nowadays the „Internet of Things” is an emerging topic. As a result, the remote access of various research equipments, as well as their ability to operate independently, plays a very important role. The study aims to present the communication interfaces of a mass spectrometer-based measuring equipment developed for determining the partial pressures and the composition of the gas mixture in a reactive magnetron sputtering process used to create wear-resistant thin-film coatings. Some of the key problems that appeared during the development process are pointed out in the paper.
\end{abstract}

Keywords: embedded system, mass spectrometer, Ethernet network, TCP server, delayed acknowledgement

\section{Összefoglalás}

Napjainkban a „Tárgyak Internete” egyre nagyobb teret nyer, és ennek eredményeképpen a kutatómunka során használt eszközök, berendezések önálló müködésre való képessége, valamint a távolról történő elérésének és irányításának lehetősége igencsak fontos szerepet tölt be. Jelen tanulmány a kopásálló vékonyréteg bevonatok előállításánál alkalmazott reaktív plazmaporlasztási folyamat gázelegyösszetételének és parciális nyomásainak meghatározására épített tömeg-spektrométer alapú mérőberendezés kommunikációs interfészeit kívánja bemutatni, rámutatva a fejlesztési folyamat során megjelenő jellegzetesebb problémákra és ezek kiküszöbölésére.

Kulcsszavak: mikrovezérlös beágyazott rendszer, tömegspektrométer, Ethernet hálózat, TCP szerver, késleltetett nyugtázás

\section{Bevezető}

A „Tárgyak Internete” egy feltörekvő téma, amely az mindennapi élet, az ipar és a kutatás valamennyi területét érinti. Egyre több berendezéssel szemben támasztott alapvető követelmények között bukkanunk rá az irányzat sajátosságaira. A rendszerek adatot gyüjtenek, kiértékelnek, szabályoznak és természetesen képesek hálózaton keresztül történő adatcserére is.

A Sapientia Erdélyi Magyar Tudományegyetem Marosvásárhelyi Karán müködő Vékonyréteg Fizika Kutatólaboratórium 
egyik kutatási területe a kopásálló bevonatok reaktív plazmaporlasztási eljárás útján történő előállítása és tanulmányozása. A porlasztási folyamat rendkívül instabil és elengedhetetlen a paraméterek (pl. porlasztási teljesítmény, rétegnövekedési sebesség) mérése és szabályozása [3]. A konstans rétegszerkezet elérésének érdekében szükségessé vált a reaktív gázok parciális nyomásainak mérése és szabályozása. A tanulmány célja ismertetni a megépített mérőberendezés kommunikációs interfészeinek kialakítását.

\section{A beágyazott osztott rendszer}

A saját fejlesztésü beágyazott rendszer PIC32MX795F512L (32 bit-es architektúra) és dsPIC33FJ128MC706A (16 bit-es architektúra) mikrovezérlőkre épülő platform (1. ábra), amely a kvadrupól típusú tömegspektrométer és a vákuum-rendszer összes alegységének (vákuum-szivattyú, turbomolekuláris szivattyú, nyomásmérö, vízhütő rendszer) müködtetéséhez szükséges funkciók beágyazhatóságát hivatott biztosítani [1].

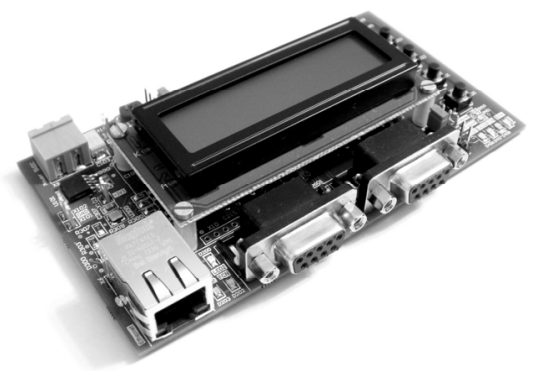

1. ábra. A saját fejlesztésü beágyazott mikrovezérlös osztott rendszer.

\section{A helyi kommunikációs hálózat felépítése}

A beágyazott osztott rendszer egyik alapvető feladata lehetővé tenni a kvadrupól típusú tömegspektrométer (QMS) távolról történő irányítását, valamint a reaktív plazmaporlasztási folyamat során kapott mérési adatok Ethernet alapú hálózaton történő elérését. Az Ethernet hálózat használatának elönye a mi esetünkben nem csak a gyors és flexibilis adatcserében, valamint az alacsony kiépítési költségekben rejlik, hanem a laboratóriumban már meglévő hálózati infrastruktúra felhasználásában is. Az eljárás segítségével csökkenteni tudtuk a beüzemelési időt, és ugyanakkor a jövőre nézve a különböző rendszermódosításokhoz szükséges fejlesztési időt is.

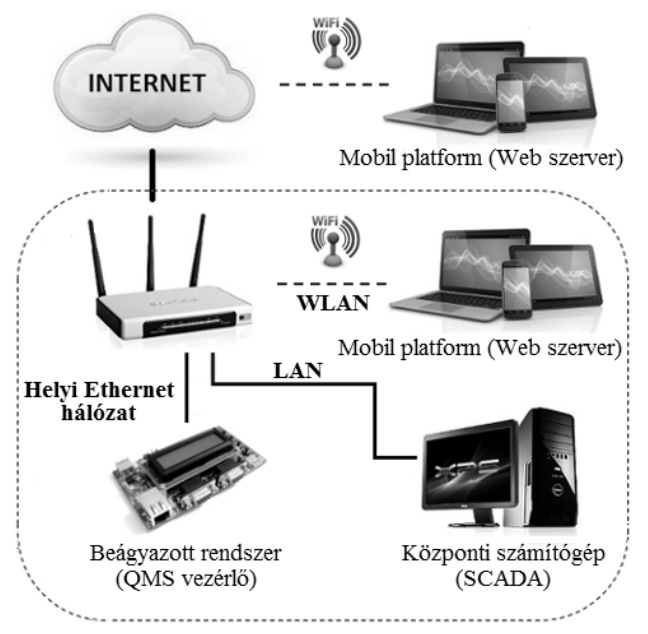

2. ábra. A laboratórium Ethernet hálózatának kialakitása és a tömegspektrométer irányitásáért felelös beágyazott osztott rendszer csatlakoztatása.

Az 2. ábra szemlélteti az Ethernet hálózat használatának egy másik tagadhatatlan előnyét is. A különféle számítástechnikai eszközök, mobil platformok egyidőben csatlakoztathatóak a hálózathoz, és ezáltal bármelyik igénybevételével könnyedén hozzáférhetünk a tömegspektrométer valamennyi paraméteréhez és a mérési adatokhoz.

Az Ethernet hálózaton keresztül történő adatcsere két legfontosabb megkötése a megbízható és vesztességmentes kommunikáció biztosítása. Ennek elérése érdekében kapcsolat alapú protokollt vettünk igénybe. Két TCP szervert ágyaztunk be 
mikrovezérlőbe (3. ábra), ezáltal két helyi (LAN) elérési lehetőséget biztosítottunk a központi számítógépen futó testreszabott SCADA alkalmazás, valamint a reaktív gázok parciális nyomásainak szabályozására készülő különálló beágyazott rendszer számára.

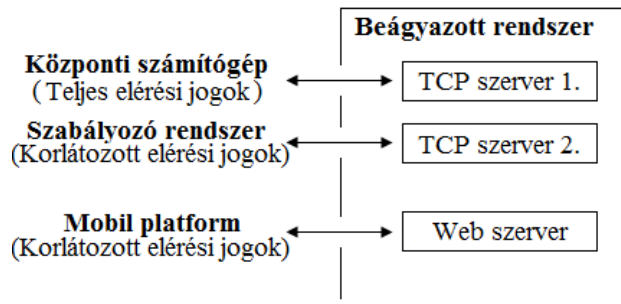

3. ábra. A beágyazott rendszer kommunikációs interfészei.

A kliens alkalmazások elöre rögzített statikus IP címek és portok ismeretében kapcsolódnak a méröberendezéshez. A két független TCP szerver implementálásával lehetőségünk nyílt különböző szintü hozzáférési jogok használatára is. A jogok hozzájárulnak a mikrovezérlő erőforrásai-nak gazdaságos használatához, főként ami a tárhely és a RAM memória felhasználását illeti, hiszen minden adatcsatorna csak dedikált csomagokat tartalmaz.

\subsection{A TCP/IP referencia modell rétegei}

A kommunikációért felelős mikrovezérlő program fejlesztésének kiindulópontja a Microchip TCP/IP stack-je [2], amelyben a különböző modulok ,látszólag párhuzamos" végrehajtásáról az együttmüködő többfeladatos feldolgozás [2] (,, Cooperative Multitasking”) gondoskodik. Ennek mintájára az alkalmazási rétegbe beágyazott saját fejlesztésű alkalmazásaink is ugyanezt a modellt követik. Voltaképp minden feladatot le kell osztani több kis részfeladatra, ügyelve arra, hogy ne legyen köztük adatfüggőség. Ez a megoldás egy véges állapotú automata implementálását feltételezi, amely lehetővé teszi a több kis részfeladat szekvenciális végrehajtását.

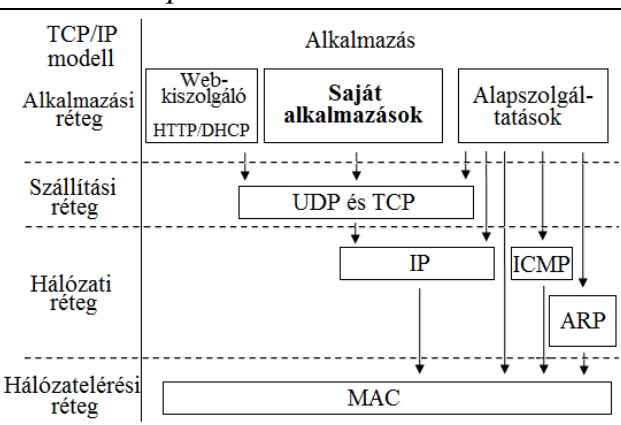

4. ábra. Mikrovezérlős alkalmazás felépitése Microchip TCP/IP Stack rétegei [2].

Mivel az együttműködő feldolgozás esetében nincs felsőbb szintü arbitráló egység, ezért alapkövetelmény a kivárásos függvények elkerülése, valamint a részfeladatok maximális végrehajtási idejének korlátozása, annak érdekében, hogy egyetlen algoritmus se monopolizálja a rendszer erőforrásait. Tanulmányozva a stack felépítését, valamint figyelembe véve a saját megkötéseinket, ezt a maximális időt 3ms-ra rögzítettük, valamint az egy ciklus alatt végrehajtható részfeladatok maximális számát 30-ra korlátoztuk.

\subsection{A TCP szerver}

A fejlesztés során sikerült megoldást találnunk a TCP protokollba beépített késleltetett nyugtázás (,,Delayed Acknowledgement") által eredményezett jelentős adatátviteli sebességkorlátozásra is. A késleltetett nyugtázás a csomagonkénti visszajelzésből adódó fölösleges adatforgal-mat hivatott csökkenteni, azonban jelenléte a sajátos alkalmazásunkban hátrányt jelentett.

Hibrid kommunikációról beszélhetünk, hiszen a szerver kérésre is, de önállóan is kezdeményezhet adatküldést.

A protokoll szerint, minden csomag sikeres átvételét a kliensnek nyugtáznia kell, hiszen csak ekkor történik meg a szerver alkalmazás bufferének kiürítése és a soron következő csomag betöltése. Amennyiben a kliens alkalmazás nem jelez vissza, egy 200ms-os időkorlát túllépése után automa- 
tikusan engedélyeződik a szerver kimeneti bufferének ürítése, de ez jelentős sebességcsökkenést eredményez (5. ábra I. eset). Két módon kerülhető el a jelenség: a kliens minden egyes megkapott csomagra küld egy választ (akár hasznos információ nélkül), ehhez csatolva az előző üzenet nyugtázását, vagy a szerver két egymás utáni csomagot küld, amelyek után a kliensnek kötelező módon nyugtáznia kell a sikeres átvételt. Mi a második megoldást választottuk, amely feltételezi a szerver oldalon az adott csomag felbontását két részcsomagra (5. ábra II. eset). A hiba kiküszönölésére implementált módszer lehetővé tette a $\mathrm{Mb} / \mathrm{s}$ nagyságrendủ adatátviteli sebesség elérését a beágyazott rendszer és a számítógépes alkalmazás között.

I. eset

\section{II. eset}

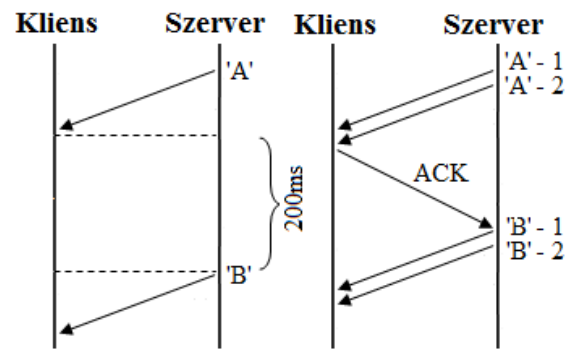

5. ábra. Adatcsere a beágyazott rendszer és a számitógépes alkalmazás között.

A sajátos alkalmazásunk különböző méretủ adatcsomagok használatát feltételez-te, amelyek bájt és kilóbájt nagyságrendüek is lehetnek. Ennek eredményeképpen felmerült egy másik kérdés: hogyan választjuk meg a TCP szerver kimeneti bufferének méretét? Amennyiben a legnagyobb csomag méretét vesszük alapul, pazaroljuk a mikrovezérlő memóriáját, viszont ha egy kisebb méretet definiálunk, akkor az ennél nagyobb méretü csomagokat akár több részre is fel kell osztani, és ez a művelet többlet számítási kapacitást igényel. Az általunk javasolt megoldás a leggyakrabban használt csomag méretének megfelelően megválasztani a kimeneti buffert.

Mindkét esetet gyakorlatban is megvizsgáltuk, s figyelemebe véve az elenyésző sebességbeli különbséget, cél-szerübbnek találtuk a második, memória-takarékosabb módszert alkalmazni.

\section{Következtetések}

A fejlesztési munka során sikerült egy olyan beágyzott rendszert kialakítanunk, amely Ethernet hálózatra csatlakozva lehetővé teszi a mérőberendezés paramétereinek és mérési eredményeinek táblagép, okos telefon, számítógép, vagy akár más beágyazott rendszer segítségével történő elérését. A kidolgozott algoritmusok, sajátos megoldások hozzájárultak a beágyazott rendszer erőforrásainak optimális felhasználásához.

\section{Köszönetnyilvánítás}

Köszönjük Dr. Bíró Domokosnak, Dr. Papp Sándornak és Dr. Kelemen Andrásnak a mérőberendezés tervezése és kialakítása során nyújtott nélkülözhetetlen segítségüket.

\section{Szakirodalomi hivatkozások}

[1] Fekete, A.-Zs.; Jakab-Farkas, L.: Parciális nyomások mérésére alkalmas beágyazott rendszer fejlesztése reaktiv porlasztóberendezés számára. A XV. Műszaki Tudományos Ülésszak Előadásai, EME kiadó, Kolozsvár, 2014. november 22., http://eda.eme.ro/handle/10598/28465, 87-90

[2] *** TCP/IP programcsalád leírása: Microchip TCP/IP Stack Help (verzió: 5.42.08 - 2013).

[3] Fekete, A.Zs., Jakab-Farkas, L., Papp, S., Balogh, T.Cs.: Dynamic Pressure Control in Reactive Sputtering Process. Acta Universitatis Sapientiae, Electrical and Mechanical Engineering 4, 2012, pp. 33-44. 